\title{
RANCANG BANGUN SISTEM PENJERNIHAN AIR OTOMATIS BERDASARKAN TURBIDITYMETER BERBASIS MIKROKONTROLLER
}

\author{
Affan Bachri ${ }^{1}$, Afif Julianto ${ }^{2}$ \\ ${ }^{1,2}$ Program Studi Teknik Elektro, Fakultas Teknik, Universitas Islam Lamongan \\ Jl. Veteran No. 53A Lamongan \\ Telp. 0322 - 324706, Fax. 0322 - 317116 \\ E-mail:avanbe@gmail.com, afifjulianto13@gmail.com
}

\begin{abstract}
The turbidity sensor works by reading the water particles turbidity level captured by the Light Dependent Resistor (LDR) that has been emitted by the laser light. Therefore, the LDR resistance score changes and it makes the Nephelometric Turbidity Units (NTU) score also changes. The solenoid valve is controlled by the suitability of the readings of the desired turbidity meter sensor by the operator.
\end{abstract}

\section{Keywords: turbidity sensor, solenoid valve, LDR}

\section{PENDAHULUAN}

Air merupakan salah satu kebutuhan pokok dalam kehidupan makhluk hidup di bumi ini. Air digunakan untuk proses metabolisme tubuh baik bagi manusia, hewan maupun makhluk hidup lainnya. Selain itu air juga digunakan oleh manusia untuk memenuhi kebutuhan hidup lainnya misalkan tempat rekreasi, pembangkit energi listrik, transportasi, dan pengairan pertanian.

Keasaman atau $\mathrm{pH}$ air sangat penting bagi tubuh kita karena bila air yang kita minum memiliki $\mathrm{pH}$ yang rendah kebutuhan dalam tubuh kita tidak terpenuhi dengan maksimal. Air yang baik untuk konsumsi memiliki nilai pH 6,5 - 8,5 (Permenkes RI, nomor 907/MENKES/SK/VII/2002 tanggal 29 Juli 2002, tentang, syarat - syarat dan pengawasan kualitas air minum).

Selain itu, air yang baik tidak mengandung logam berat. Seperti yang diketahui, air yang keruh salah satu ciri air yang tidak sehat. Kekeruhan disebabkan adanya kandungan partikel terlarut dalam air baik yang bersifat organik maupun anorganik. Zat organik berasal dari lapukan tanaman dan hewan, sedangkan zat anorganik berasal dari lapukan batuan dan logam. Dengan adanya zat organik pada air dapat menjadi makanan bakteri sehingga mendukung perkembangannya. Kekeruhan dalam air minum tidak boleh melebihi 5 NTU (Nephelometric Turbidity Unit) (Permenkes RI, nomor 416/MEN.KES/PER/IX/1990, tentang syaratsyarat dan pengawasan kualitas air).

Oleh karena itu, penulis Penulis merencanakan membuat alat kekeruhan air guna mempermudah mengidentifikasi air yang akan di gunakan. Alat yang penulis rancang memiliki kesamaan fungsi dengan alat pengukur $\mathrm{pH}$ air atau $\mathrm{pH}$ meter dan pengukur kekeruhan air atau turbidymeter otomatis berbasis ATMega328P. Alat ini menggunakan dua sensor yaitu sensor kekeruhan sehingga memiliki keluaran yaitu nilai kekeruhan air.

Rumusan masalah yang didapat adalah bagaimana menggunakan sensor turbidity untuk membaca kekeruhan air dan bagaimana merancang alat penjernih air otomatis berdasarkan hasil pembacaan turbiditymeter.

Adapun batasan masalah dalam penelitian ini adalah hanya menggunakan sensor turbidity untuk membaca kekeruhan air dan alat digunakan untuk menjernihkan air secara otomatis sesuai pembacaan sensor turbidity.

Tujuan dari penelitian ini adalah mengetahui cara kerja sensor turbidity untuk membaca kekeruhan air dan dapat merancang rangkian alat penjernih air otomatis dengan pembacaan hasil turbiditymeter.

\section{METODE}

Tahap penelitian dilakukan dengan perancangan perangkat keras, perancangan perangkat lunak dan dilakukan uji fungsi dan analisa sistem yang dibuat.

\subsection{Perancangan Perangkat Keras}

Perancangan perangkat keras terdiri dari perancangan sensor turbiditymeter, perancangan LCD, dan perancangan solenoid valve.

\subsubsection{Perancangan Sensor Turbiditymeter}

Turbiditymeter merupakan alat pengujian kekeruhan dengan sifat optik akibat dispersi sinar dan dapat dinyatakan sebagai perbandingan cahaya yang dipantulkan terhadap cahaya yang datang. Alat ini banyak digunakan dalam pengolahan air bersih untuk memastikan bahwa air yang akan digunakan memiliki kualitas yang baik dilihat dari tingkat kekeruhanya. Rangkaian skema alat seperti pada gambar 1 . 


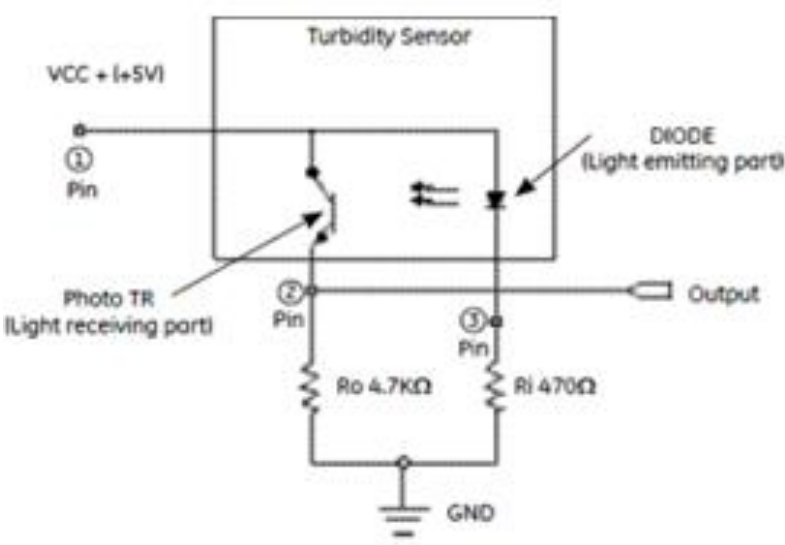

Gambar 1. Skema perancangan sensor turbiditymeter

\subsubsection{Perancangan Penampil LCD}

Data diterima oleh turbiditymeter kemudian data diolah oleh mikrokontroller dan data akan ditampilkan. Tampilan yang digunakan adalah LCD 16x2, dimana LCD ini mempunyai 16 kolom dan 2 baris. LCD berfungsi untuk menampilkan data yang telah diolah yaitu berupa hasil pengukuran kejernihan air. Perancangan pengujian dapat dilihat pada gambar 2 .

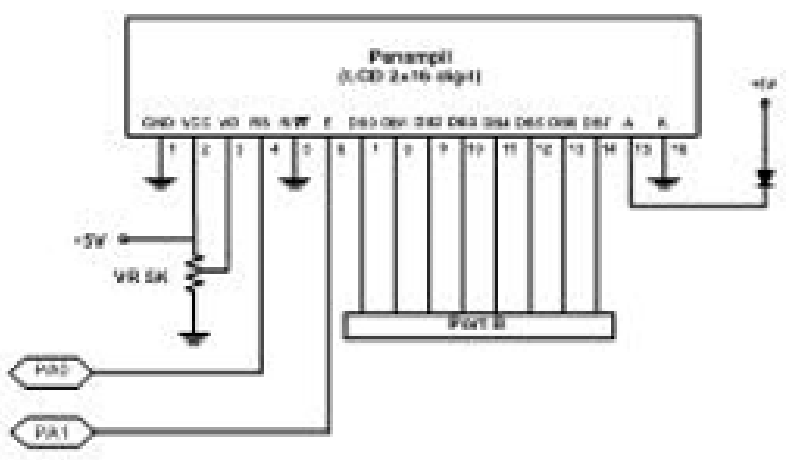

Gambar 2. Perancangan LCD

\subsubsection{Perancancangan Selenoid Valve}

Selenoid Valve adalah katup yang digerakan oleh energi listrik melalui solenoida, mempunyai kumparan sebagai penggeraknya yang berfungsi untuk menggerakan piston yang dapat digerakan oleh arus AC maupun DC.

\subsection{Perancangan Perangkat Lunak (Software)}

Pemrograman mikrokontroller ATMega 328 ditulis menggunakan software arduino IDE dengan sketch/code berdasarkan flowchart untuk memudahkan pembuatan program. Flowchart perancangan perangkat lunak dapat dilihat pada gambar 3 .

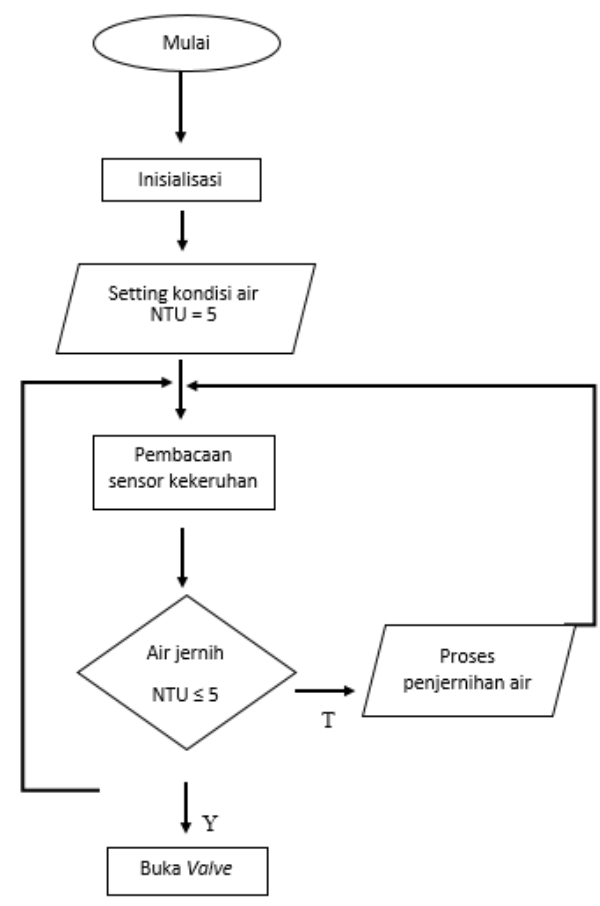

Gambar 3. Flowchart perancangan perangkat lunak

\section{PEMBAHASAN}

\subsection{Hasil Pengujian}

Hasil pengujian menampilkan hasil pengujian masing-masing bagian dari sistem yang direncanakan, yakni; pengujian sensor turbidity meter, pengujian penampil LCD dan pengujian solenoid valve. Baru dilanjutkan ke pengujian keseluruhan sistem.

a. Pengujian Sensor Turbiditymeter

Pengujian sensor dilakukan untuk mengetahui rancangan yang dibuat mampu memberikan respon terhadap setiap perubahan tingkat kekeruhan air. Langkah - langkah untuk melakukan pengujian pada sensor turbidity, yaitu menyiapkan sensor turbidity yang dihubungkan pada arduino dan dimasukkan program ke dalam IC mikrokontroller. Hasil pengujian dapat dilihat pada tabel 1 , dan grafik pengujian sensor dapat dilihat pada gambar 3 .

Tabel 1. Hasil pengujian sensor turbiditymeter

\begin{tabular}{ccc}
\hline No & $\begin{array}{c}\text { Tegangan } \\
\text { (Volt) }\end{array}$ & NTU \\
\hline 1 & 4,64 & 0,55 \\
2 & 4,49 & 3,08 \\
3 & 4,33 & 6,93 \\
4 & 4,21 & 18,6 \\
5 & 3,74 & 160 \\
6 & 2,8 & 910 \\
\hline
\end{tabular}




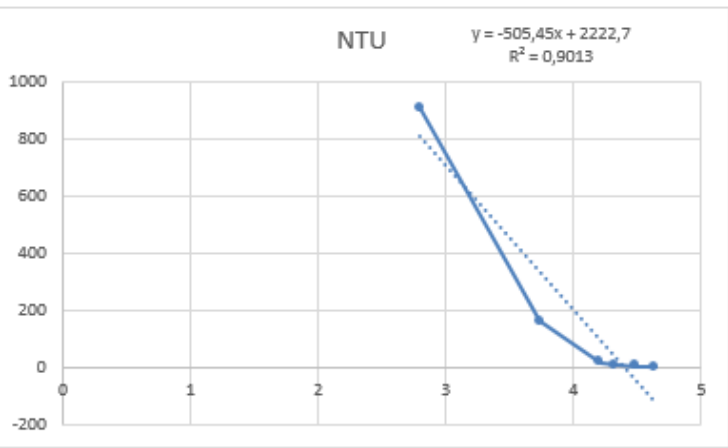

Gambar 3. Grafik pengujian sensor turbiditymeter

\section{1) Pengujian LCD}

Pengujian LCD menggunakan board Arduino Uno sebagai alat untuk memerintahkan LCD menampilkan berbagai macam karakter sesuai keinginan, dengan cara memasukkan program kedalam IC mikrokontroller ATMega 328. Hasil pengujian LCD dapat dilihat pada gambar 4.

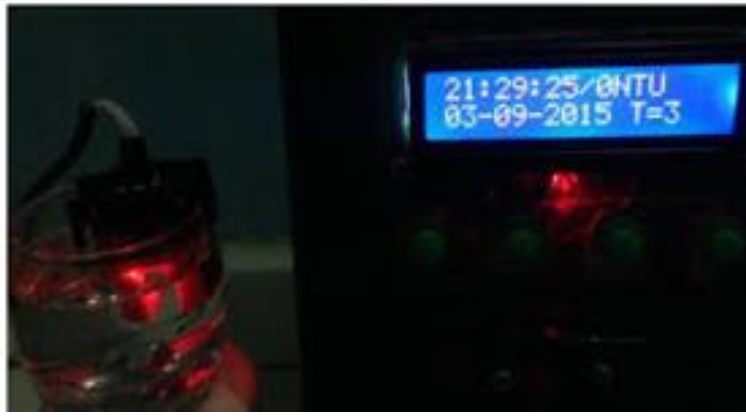

Gambar 4. Hasil pengujian LCD

\section{2) Pengujian Selenoid Valve}

Pengujian solenoid valve ini dilakukan dengan memberikan aliran arus listrik pada bagian input solenoid valve. Dengan begitu katup pada solenoid valve akan terbuka secara otomatis. Dan apabila sudah tidak ada arus listrik yang mengalir maka katup akan tertutup kembali.

Tabel 3. Hasil pengujian selenoid valve

\begin{tabular}{ccc}
\hline No & Input & Status \\
\hline 1 & 220 Volt & On \\
2 & 0 Volt & Off \\
\hline
\end{tabular}

\section{3) Pengujian Alat Secara Keseluruhan}

Tahap ini bertujuan untuk mengetahui kinerja rangkaian secara keseluruhan yang meliputi pengujian sensor turbidity, tampilan LCD, dan pengujian selenoid valve. Hasil pengujian dapat dilihat ada tabel 4 .
Tabel 2. Hasil pengujian secara keseluruhan

\begin{tabular}{ccccc}
\hline No & Percobaan & $\begin{array}{c}\text { Nilai } \\
\text { Kekeruhan }\end{array}$ & Tegangan & $\begin{array}{c}\text { Selenoid } \\
\text { Valve }\end{array}$ \\
\hline 1 & Air Jernih & 0 & 4,85 volt & On \\
2 & Aqua Ades & 0 & 4,85 volt & On \\
3 & Air Kopi & 433 & 0.82 volt & Off \\
4 & Air Sabun & 170 & 0,56 volt & Off \\
5 & Air Gula & 1 & 1,7 volt & On \\
\hline
\end{tabular}

\subsection{Pembahasan}

Kinerja rangkaian secara keseluruhan yang meliputi pengujian sensor turbidity, tampilan LCD, dan pengujian selenoid valve. tingkat kekeruhan air mempengaruhi sistem kerja dari selenoid valve. Semakin besar nilai kekeruhan yang dibaca oleh sensor, maka selenoid valve yang bekerja sebagai aktuator akan menutup, dengan nilai limit kekeruhan 5. Sedangkan apabila nilai kekeruhan air yang dibaca kurang dari 5, maka selenoid valve yang bekerja sebagai aktuator akan membuka.

\section{KESIMPULAN}

1) Sensor turbidity digunakan untuk mendeteksi kekeruhan air dengan menggunakan alat pembanding NTUmeter type $\mathrm{HACH} 2100 \mathrm{Q}$ dengan range $0-1000$ NTU. Semakin besar tegangan, maka semakin kecil nilai NTU yang didapat. Sedangkan semakin kecil tegangan, maka semakin besar nilai NTU yang didapat.

2) Alat penjernih air otomatis dirancang dengan menggunakan beberapa komponen seperti sensor turbidity, mikrokontroller ATMega328, selenoid valve, dan LCD yang telah terintegrasi. Sehingga sensor turbidity dapat membaca kekeruhan air dan didapat nilai terendah sebesar 0,55 NTU dengan besar tegangan 4,64 volt. Dan nilai tertinggi sebesar 910 NTU dengan besar tengangan 2,8 volt.

\section{PUSTAKA}

Akip Saputra, (2016). PENGUKUR KADAR KEASAMAN DAN KEKERUHAN AIR BERBASIS ARDUINO. Universitas Muhammadiyah Surakarta

Bachri, A. (2017). Rancang Bangun Sistem Deteksi Kebakaran Gedung di Universitas Islam Lamongan Berbasis Mikrokontroller Menggunakan Radio Frekuensi. Jurnal Elektro, 2(2), 6.

Kho, Dickson, (2014), Prinsip Kerja DC Power Supply(Adaptor),

http://teknikelektronika.com/prinsip-kerja-dcpower-supply-adaptor, diakses 12 Januari 2018.

Menteri Kesehatan, (2010). Tentang Persyaratan Kualitas Air Minum Nomer 492/MENKES/PER/IV/2010 
Nike Ika Nuzula, (2013). RANCANG BANGUN ALAT UKUR KEKERUHAN BERBASIS MIKROKONTROLLER. Institut Teknologi Sepuluh November

Samsudin Widya yanuar,(2015), kendali valve secara Otomatis berdasarkan tingkat kekeruhan (turbidity) air berbasis arduino,laporan proyek akhir D3, Universitas Gadjah Mada, Yogyakarta

https://www.hackteria.org/projects/turbidity-meter/ Diakses pada 21 Januari 2018

http://www.kitomaindonesia.com/article/9/solenoidvalve-pneumatic-prinsip-kerja Diakses pada tanggal 21 Januari 2018

http://saptaji.com/2016/06/26/menampilkan-helloworld-di-arduino-dengan-lcd-shield/ Diakses pada tanggal 21 Januari 2018 